\title{
THE INFLUENCE OF PERCEIVED ORGANIZATIONAL SUPPORT AND SELF EFFICACY ON WORK ENGAGEMENT AT PT BHUMI BHAKTI SUKSES PERSADA
}

\author{
Sagita Noviyandini Conoras ${ }^{1}$ \\ ${ }^{1}$ Faculty of Economics, State University of Jakarta \\ Jakarta, Indonesia \\ Sagitaconoras@gmail.com \\ Dr. Widya Parimita, S.E., M.P.A ${ }^{2}$ \\ ${ }^{2}$ Faculty of Economics, State University of Jakarta \\ Jakarta, Indonesia \\ Widya.parimita@gmail.com \\ Dr. Agung Wahyu Handaru, S.T., M.M. ${ }^{3}$ \\ ${ }^{3}$ Faculty of Economics, State University of Jakarta \\ Jakarta, Indonesia \\ Agungsq127@gmail.com
}

\begin{abstract}
The purpose of this study is: 1) To find out the description of perceived organizational support, self-efficacy, and work engagement. 2) To find out the influence of perceived organizational support on work engagement. 3) To find out the influence of self-efficacy on work engagement. 4) To find out the influence of perceived organizational support and self-efficacy on work engagement. The study used 70 respondents as a sample. The survey method was used as a data collection technique by distributing questionnaires, and then the results of the questionnaire were processed using SmartPLS version 3. The result obtained from PLS analysis shows a positive and significant influence between perceived organizational support and self-efficacy on work engagement. Variable of perceived organizational support and self-efficacy can influence work engagement in employees of PT Bhumi Bhakti Sukses Persada with t-statistical value for the perceived organizational support variable on work engagement $(3,638>1.96)$ and signification value of $(0.000<$ 0.005), for self-efficacy variables to work engagement, has an at-statistical value of $(2,876>1.96)$ and a significance value of $(0.004<0.05)$. In contrast, perceived organizational support and self-efficacy towards work engagement have an at-statistical value of $(21,990>1.96)$ with a value of significance $(0.000<0.05)$.
\end{abstract}


Keyword : Perceived Organizational Support, Self Efficacy, Work Engagement, Employee

\section{INTRODUCTION}

In an organization, human resources are one of the most important factors for sustainability and have a role as implementers who work for various organization activities. Organizations need human resources that are active in engaging, fully responsible for the organization's sustainability, and have high initiatives in working. Dedicated human resources and high initiatives are also needed by organizations; for example, are human resources who have an engagement in living their working lives (Leiter \& Bakker, 2010).

There are surveys conducted by Gallup about the working engagement that occurs between the company and employees in Indonesia. This survey was conducted using data from 2011 to 2012, where the results stated that only about $8 \%$ of employees in Indonesia have a greater interest in their employees and for $77 \%$ of employees belong to the category of not engaged and there are $15 \%$ of employees fall into the category of actively disengaged. The results of a survey conducted by Gallup in 2016 of employees in Indonesia stated that as many as $80 \%$ of employees in Indonesia feel no sense of belonging to their company. According to a report by the State of Global Workplace in 2017, the average individual who works full-time and falls into the engaged category is only 15 per cent. In contrast, $85 \%$ of individuals who work or employees feel unengaged and unhappy with their employees.

Various ways can be done by the company in making the engagement that occurs between employees and the company, among others by increasing the trust of employees to the company so that they believe that the contribution they make to the company has a good effect and the company appreciates it (Albrecht, 2010). According to the results of the job street survey in 2020, since COVID-19, employees have decreased satisfaction with the quality of life from $93 \%$ to only $38 \%$. Then there is the percentage result of the happiness level of employees, where before COVID-19 occurred, 89\% of employees were happy with their work. Currently, only $49 \%$ of employees are happy with their work. 
Employees who have an engagement to the organization they occupy will develop themselves to achieve the interests of the organization, take the initiative and be more active, strengthen support for the organization's culture and organizational values, always focus and be vigilant, and have confidence that they can create different things within the organization (Macey, 2006). But this is different from the results of the survey conducted by JETRO. There was a survey conducted by JETRO (Japan External Trade Organization) from August to September 2019 using 13,458 companies as their respondents. In Indonesia, the survey was conducted on 1,726 Japanese companies. This survey was conducted to see the current condition of Japanese company business in Asia and Oceania. In CNN Indonesia (2020), The results of this survey stated that there are as many as $55.8 \%$ of companies that are respondents are dissatisfied with the productivity of the Indonesian workforce. The level of dissatisfaction with Indonesia's workforce is much higher than the southeast Asian country average of $30.6 \%$.

The reality of the survey results for perceived organizational support, self-efficacy, and work engagement has differences with the results of previous research conducted by Hasnida et al. (2019), Sulistyo \& Suhartini (2019), and others which states that perceived organizational support and self-efficacy has a positive and significant effect on work engagement. This indicates an irregularity between the two results. Therefore, the researcher intends to examine " The Influence of Perceived Organizational Support and Self Efficacy on Work Engagement", which will be carried out on PT Bhumi Bhakti Sukses Persada. The problem formula used is: 1) Does perceived organizational support positively and significantly affect work engagement to employees of PT Bhumi Bhakti Sukses Persada?, 2) Does self-efficacy positively and significantly affect work engagement to employees of PT Bhumi Bhakti Sukses Persada?, 3) Does perceive organizational support and self-efficacy have a positive and significant effect simultaneously on work engagement to employees of PT Bhumi Bhakti Sukses Persada?

\section{LITERATURE REVIEW}

\section{Work Engagement}

There is a definition put forward by Schaufeli et al. (2002), which states that work engagement is a thing that provides satisfaction and is characterized by a positive mental 
state and can be described through vigour, dedication, and absorption dimensions. Whereas according to Schmidt (2004), work engagement can also be interpreted as a combination of commitment and satisfaction. This commitment refers more to the motivational and physical elements, while self-satisfaction involves more emotional or attitude elements. Robbins and Judge also define work engagement as the degree to which individuals will feel bound, satisfied, and feel enthusiasm for the work they are doing (Robbins \& Judge, 2017).

According to Schaufeli et al. (2002), dimensions that support work engagement variables are vigour, dedication, absorption. This dimension is supported by the indicator expressed by W. B. Schaufeli \& Bakker (2004): 1) High energy and strength levels, 2) Willing to invest in a business, 3) It is not easy to experience fatigue, 4) Persistent in the face of difficulties that hinder, 5) Feel the significance of an individual's task, 6) Feel enthusiasm and pride in the work, 7) Inspired and challenged by the work you have, 8) Volunteering for a job, 9) Difficulty in disengaging from work. Work engagement is influenced by factors stated by Bakker \& Demerouti (2008): 1) Job Demands, 2) Job Resources, 3) Personal Resources.

\section{Perceived Organizational Support}

There is a definition put forward by Rhoades \& Eisenberger (2002) that perceived organizational support (POS) is an employee's trust in the organization in which they work on whether the organization values contributions, cares for the welfare and can treat its employees fairly. Whereas according to Neves \& Eisenberger (2014), perceived organizational support (POS) can be defined as everything about the perception that employees have that companies value every contribution made by them and companies care about their well-being. Robbins and Judge state that POS or perceived organizational support is the trust of employees in the company regarding appreciation for the contributions and services provided and can care about their well-being (Robbins \& Judge, 2017).

According to Rhoades \& Eisenberger (2002), dimensions that support perceived organizational support variables are fairness, supervisor support, and organizational reward and job condition. This dimension is supported by the indicator expressed by Rhoades \& Eisenberger (2002): 1) Organizations reward employee contributions, 2) The 
organization rewards more efforts made by employees, 3) Organizations can pay attention to all the difficulties that employees are facing, 4) Organizations can provide concern about the welfare of employees, 5) Organization directs employees when they're not doing their job properly, 6) Organizations pay attention to work so as to provide satisfaction to employees, 7) Organizations paying 100,000 attention to employees, 8) The organization has a feeling of pride in the achievements of employees in working. Perceived organizational support is influenced by factors stated by Ghani \& Hussin (2009): 1) Trust, 2) Access to information, 3) Access to the opportunity to learn and develop.

Previous research conducted by Utari et al. (2021) on 72 employees in the heavy equipment division of PT Pindad (Persero) found that there is a significant influence between perceived organizational support for work engagement. Employees who have the support of the company will improve the abilities, skills, knowledge, and attitudes they had before. Similarly, research conducted by Sunarjo et al. (2020), Najeemdeen et al. (2018), Sitorus (2018) found that in their studies, their perception of organizational support had a positive and significant effect on work engagement. Perceived organizational support that employees have grown because the company provides what is needed by employees then there is a reciprocal relationship. Perceived organizational support will increase employee motivation and their willingness to be tied to where they work.

\section{Self Efficacy}

There is a definition put forward by Friedman \& Schustack (2008) self-efficacy is an individual's trust in their ability to do things in the form of future behaviour. Whereas according to Niu (2010), self-efficacy can be defined as something resulting from interactions between external or external environments, self-adjustment mechanisms, individual abilities, experiences, and education owned by each individual. Cervone \& Pervin state that selfefficacy is what a person has based on experience and expectations that are able to influence an individual (Cervone \& Pervin, 2012).

According to Bandura (1997), dimensions that support the self-efficacy variable are level, strength, and generality. This dimension is supported by the indicator expressed by: 1) Confident that you can handle your tasks effectively and efficiently, 2) Confident that you 
can handle situations and conditions that are happening or will be faced 3) Be confident in the efforts that are being made and increase the effort when faced by failure, 4) Confident to control the stress and threats faced, 5) Trust in your abilities, 6) Believing that difficulty is a challenge that can be faced is not an obstacle, 7) Focus on tasks and strategies in the face of difficulties in task work, 8) Rise quickly from a failure. Self Efficacy is influenced by factors stated by: 1) Mastery experience/ Performance accomplishment, 2) Vicarious experience, 3) Social persuasion, 4) Physiological/ Emotional State.

Previous research conducted by Trilolita (2017) on 92 employees of PT Telekomunikasi Indonesia Regional V Surabaya found that there is a significant influence between selfefficacy on work engagement. Employees with high self-efficacy have a high sense of enthusiasm in work, even sometimes to work things that exceed their duties based on the contract. Similarly, the research conducted by Darokah (2016), Pulungan \& Rivai (2021), Ariani \& Nugroho (2019) also found that in their research, self-efficacy has a positive and significant effect on work engagement. Employees who believe in their abilities will tend to do their best either as individuals or as members of the company. In addition, the increase in self-efficacy owned by employees will cause the performance they have increased even with an increase in productivity while they work.

\section{Theoritical Framework}

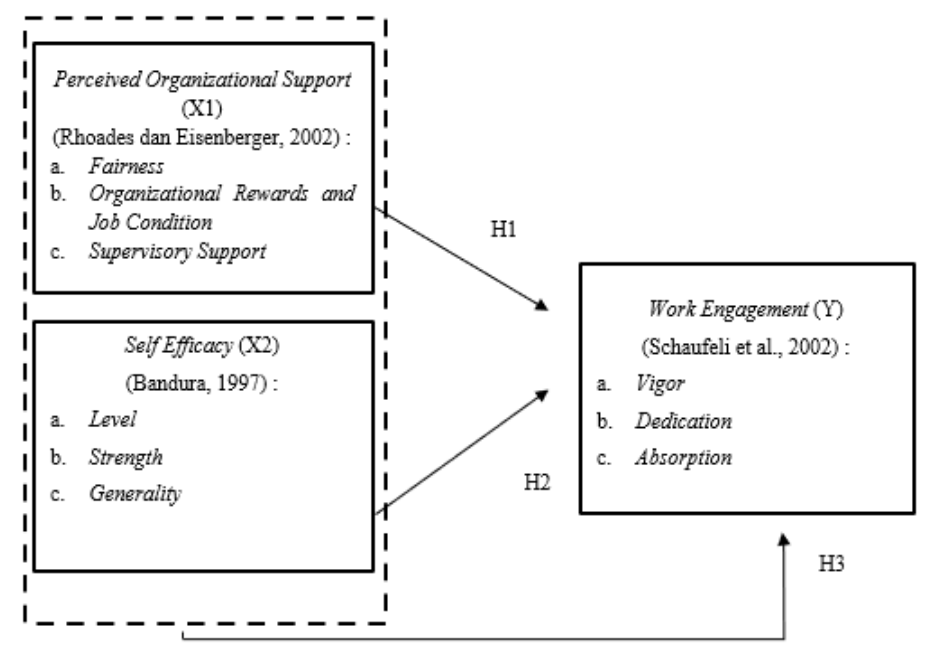

Figure 1. Framework

\section{Hypothesis}

Source : Data proccesed by author (2021)

Based on the explanations and previous research, the researcher can determine the research hypothesis as follows :

H1: Perceived organizational support positively and significantly affect work engagement 
H2: Self-efficacy positively and significantly affect work engagement

H3: Perceived organizational and self-efficacy positively and significantly have an effect simultaneously toward work engagement.

\section{RESEARCH METHOD}

\section{Time and Place}

The research began in February 2021, with the dissemination of pre-research questionnaires to companies to get an idea of the problems that occur in the company regarding work engagement. After that, the research was carried out until August 2021. The research was conducted at PT Bhumi Bhakti Sukses Persada. The company is located in Kompleks Bukit Gading Mediterania A No. 2, Kelapa Gading North Jakarta.

\section{Research Design}

This study uses quantitative survey research by collecting data through research instruments by disseminating questionnaires to employees of PT Bhumi Bhakti Sukses Persada company whose results will be processed using PLS (Partial Least Square) uses SmartPLS version 3.0 as software and in this study used the main data. This study also uses descriptive and explanatory approaches with the aim of testing a hypothesis or theory. This is used to strengthen or reject hypotheses or theories from the results of previous studies.

\section{Population and Sample}

In this study, the population used was all employees at PT Bhumi Bhakti Sukses Persada. Employees at this company numbered 203 individuals. Simple random sampling is a sampling technique used in this study. To find out how many samples should be used in this study, the researchers used the solvin formula for the sample calculation. From the use of slovin formula, the samples produced is 67 . In order for the data used to be even, the sample is rounded into 70 samples.

\section{Measurement Scale}

This study used a Likert scale for its measurement scale. By using the Likert scale as the measurement scale, the variable to be measured will be described and converted into a variable indicator. In this study, the Likert scale used to submit instrument items used intervals of five (a five-point Likert scale). 


\section{Data Collection Techniques}

Researchers used questionnaires as well as interviews as a medium to collect primary data. The questionnaire was distributed to employees at PT Bhumi Bhakti Sukses Persada. Meanwhile, interviews were conducted with several employees at PT Bhumi Bhakti Sukses Persada to support the writing of problems on the background of the research.

\section{Data Analysis Techniques}

In this research, the method used PLS (Partial Least Square) and SmartPLS version 3.0 for the software. PLS is a model that provides a model description of complex structures.

\section{Outer Model}

An outer model is a model to measures how each indicator can relate to it is latent variables.

\section{Convergent Validity}

Convergent validity has a principle that states that in the measurement of data used from a construct, the correlation must be high. The expected value in the convergent validity test using SmartPLS version 3 can have a value of $>0.7$ or in some studies often used a limit of 0.6 as a minimum limit of the result of the value of loading factors (Ghozali \& Latan, 2015).

\section{Discriminat Validity}

Discriminant Validity or discriminant validity has a relationship with the principle that different constructs manifest in a study should not have a high correlation. If the value of AVE in each construct is above the number 0.5 , then there is no problem with the validity of the model discriminant being tested so that the construct in the research model can be said to have good discriminant validity. In addition, to measure the discriminant validity of a model can be seen through the value of the loading factor produced must be $>0.7$ (Ghozali \& Latan, 2015).

\section{Cronbach's Alpha}

The use of cronbach's alpha in testing the reliability of the construct will result in a lower value (under estimate) so it is recommended to use composite reliability in reliability testing for a construct. A variable will be declared reliable if the resulting cronbach's alpha value $>0.70$ for all constructs (Ghozali \& Latan, 2015). 


\section{Composite Reliability}

Composite reliability and cronbach's alpha are called Dillon-Goldstein's. Reliability test in using outer model can be strengthened through composite reliability. The limit rule that is usually used to observe the reliability of a construct is that the resulting composite reliability value must be greater than 0.7 for research that is confirmatory, while for research that is exploratory the value of 0.6-0.7 is still acceptable (Ghozali \& Latan, 2015).

\section{Inner Model}

The inner model evaluation can be done through three analyses, namely by observing the values of $\mathrm{R}^{2}, \mathrm{Q}^{2}$, and $\mathrm{F}^{2}$.

\section{R-Square}

Changes in the resulting value in R-Square can serve as a guideline in describing the influence that occurs between exogenous variables and endogenous variables. The coefficient of path values in R-Square may indicate a degree of significance in hypothesis testing. If the resulting $\mathrm{R}^{2}$ value is greater, it indicates a better level of determination.

Here is an explanation of the indication of the value of $\mathrm{R}$-squares : $0.75=\mathrm{X}$ influence on strong $\mathrm{Y}, 0.50=\mathrm{X}$ influence on moderate $\mathrm{Y}$, and $0.25=\mathrm{X}$ influence on weak $\mathrm{Y}$ (Ghozali \& Latan, 2015).

\section{Q-Square}

If the value resulting from $\mathrm{Q}^{2}$ is above zero, it indicates that there is predictive relevance of the model over endogenous latent variables. Conversely, if the value of $\mathrm{Q}^{2}$ produced < 0 then indicates a less predictive relevance model (Ghozali \& Latan, 2015).

\section{F-Square}

F-square aims to assess how much relative influence occurs between independent variables over dependent latent variables. Here is an explanation of the F-squares value indication: 0.02 the influence of latent variables on the weak structural state, 0.15 the influence of latent variables on the medium structural state, 0.35 the influence of latent variables on the strong structural state.

\section{Hypothesis Testing}

For hypothesis testing can be observed through t-statistical values and probability values. Based on Irwan \&Adam (2015) hypothesis testing can be seen through t-statistical value with a value of 1.96 and significance level with alpha value of $5 \%$. In order for the 
hypothesis to be accepted then the t-statistical value $>1.96$ then Ha is accepted and Ho is rejected. As for accepting hypotheses using probability, if the $\mathrm{p}$ value is received $<0.05$ then $\mathrm{Ha}$ is accepted and Ho is rejected.

\section{RESULT AND DISCUSSION}

Description of The Analysis Unit. In this research, the characterization of age was dominated by employees who belonged to generation $\mathrm{Z}$ ( 31 years - 40 years) as much as $42.9 \%$. This shows that at that age, employees tend to have stability in mental, enough experience to do a job, and cognitive ability high enough to still be able to learn something new such as the use of technology today. Meanwhile, gender characteristics were dominated by men as much as $71.4 \%$. Guidance from the work of tasks in the construction company is more difficult when compared to the type of company in general, so the company needs more male employees. For the characteristics of the working period is dominated by employees with a working period of $>5$ years of $62.9 \%$. This shows that the longer an employee works in a company, the more proficient they will be at every task they have. The longer employees work, the ability they have will continue to increase because of the development of themselves to improve their abilities. The characteristic level of education is dominated by employees with bachelor's degrees by $55.7 \%$. The company chooses to use HR with a high level of education. This is because companies want the output produced by each employee to be able to meet the expectations of each user of their services.

Description of Variables. In the work engagement variable, the highest average for strongly agreed (5) and disagreeable answers (4) is in the dedication dimension with a percentage of $86.2 \%$, which, when compared to the criteria, falls into a very high category. On the other hand, the average for strongly disagreed (5) and disapproving (4) answers is highest in the absorption dimension with a percentage of $37.8 \%$, which when compared falls into the high category. In the perceived organizational support variable, the highest averages for strongly agreeable (5) and disagreeable answers (4) are in the supervisor support dimension with percentages. 76,4\%. This percentage amount, when compared using the SS $+\mathrm{S}$ score interpretation criteria, it falls into the category of good. In line with this, the item in the supervisor support dimension is "I get help from the company when 
experiencing a difficulty", with a percentage of $94.2 \%$ is the statement item with the highest percentage. In the self-efficacy variable, the highest average for strongly agreed (5) and disagreeable answers (4) is at the dimension level with a percentage of $86.6 \%$. This percentage amount, when compared using the SS $+\mathrm{S}$ score interpretation criteria, it falls into a very high category. In line with this, items in the level dimension of "I managed to do a difficult task when trying" with a percentage of $95.8 \%$ is the statement item with the highest percentage.

Partial Least Square Analysis. Outer Model. The outer model analysis is used to establish how each indicator can relate to its latent variables.

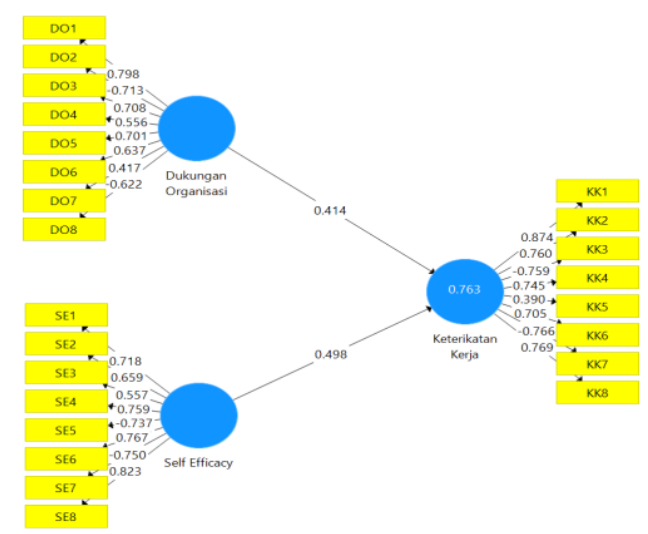

Figure 2. Result of Convergent Validity

Source : Data proccesed by author (2021)

The required value of the convergent validity test result can exceed the $>$ number of 0.7 or the frequently used limit of 0.6 as the minimum limit of the loading factor value. In the picture, it appears that there is an outer loading value on some indicators of organizational support perception variables, self-efficacy, and work engagement has loading factor values below 0.6 such as KK3, KK5, KK7, DO2, DO4, DO7, DO8, SE3, SE5, and SE6. This indicates that the indicators must be removed so that they can continue the next test. Meanwhile, loading factor with a value above 0.6 can be said to be valid and can be used in actual research. 


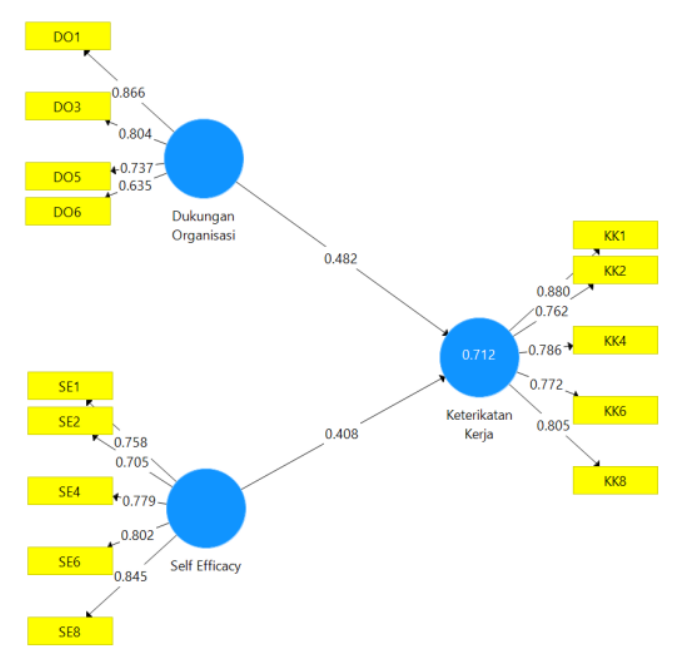

Figure 3. Result of Convergent Validity after Modification Source : Data proccesed by author (2021)

According to Ghozali \& Latan (2015), if there is an indicator with a value of $<0.60$ to correct the invalid variable, then indicators with a value of $<0.60$ or invalid should be removed from the model and not re-entered in the next test. This is in order to increase the measurement score (outer loading).

From the results of data processing with SEM PLS seen in the picture above, shows that all indicators of all variables have a loading factor value greater than 0.60 and that means that each indicator has a high validity, thus meeting the convergent validity. Thus, the analysis continued on the Discriminant Validity test.

Table 1. Result of Average Variance Extracted

\begin{tabular}{|lr|}
\hline Dukungan Organisasi & Average Variance Extracted (AVE) \\
\hline Keterikatan Kerja & 0.585 \\
\hline Self Efficacy & 0.644 \\
\hline
\end{tabular}

Source : Data proccesed by author (2021)

From the table it can be known that the AVE value for each construction is already above 0.5 . Therefore, it can be certain that there is no problem regarding the validity of convergence on the model tested so that the construction in this research model can be said to have a good convergent validity.

Discriminant Validity 
Table 2. Result of Dicriminant Validity (X1)

\begin{tabular}{|l|r|rr|}
\hline DO1 & Dukungan Organisasi & Keterikatan Kerja & Self Efficacy \\
\hline DO3 & 0.866 & 0.745 & 0.701 \\
\hline DO5 & 0.804 & 0.747 & 0.702 \\
\hline DO6 & 0.737 & 0.463 & 0.506 \\
\hline
\end{tabular}

Source : Data proccesed by author (2021)

Table 3. Result of Discriminant Validity (X2)

\begin{tabular}{|l|r|r|r|}
\hline & Dukungan Organisasi & Keterikatan Kerja & Self Efficacy \\
\hline DO6 & 0.635 & 0.387 & 0.451 \\
\hline KK1 & 0.784 & 0.880 & 0.742 \\
\hline KK2 & 0.589 & 0.762 & 0.665 \\
\hline KK4 & 0.585 & 0.786 & 0.615 \\
\hline KK6 & 0.610 & 0.772 & 0.594 \\
\hline KK8 & 0.643 & 0.805 & 0.537 \\
\hline SE1 & 0.582 & 0.635 & 0.758 \\
\hline SE2 & 0.463 & 0.530 & 0.705 \\
\hline SE4 & 0.660 & 0.605 & 0.779 \\
\hline SE6 & 0.637 & 0.629 & 0.802 \\
\hline SE8 & 0.731 & 0.674 & 0.845 \\
\hline
\end{tabular}

Source : Data proccesed by author (2021)

Table 4. Result of Discriminant Validity (Y)

\begin{tabular}{|c|c|c|c|}
\hline & & & \\
\hline & Dukungan Organisasi & Keterikatan Kerja & Self Efficacy \\
\hline DO6 & 0.635 & 0.387 & 0.451 \\
\hline KK1 & 0.784 & 0.880 & 0.742 \\
\hline KK2 & 0.589 & 0.762 & 0.665 \\
\hline KK4 & 0.585 & 0.786 & 0.615 \\
\hline KK6 & 0.610 & 0.772 & 0.594 \\
\hline KK8 & 0.643 & 0.805 & 0.537 \\
\hline
\end{tabular}

Source : Data proccesed by author (2021)

Results in each table's cross-loading estimate show that each indicator item's loading value against its construction $(\mathrm{X} 1, \mathrm{X} 2$, and $\mathrm{Y})$ has a value greater than its cross-loading value. This can be concluded that the validity of the discriminant is good for all construction. Indicators on construction indicator blocks are better than indicators in other blocks. From the results of the cross loading, it can be ascertained that there is no problem of discriminant validity.

Table 5. Result of Cronbach's Alpha

\begin{tabular}{|lr|}
\hline & Cronbach's Alpha \\
\hline Dukungan Organisasi & 0.772 \\
\hline Keterikatan Kerja & 0.861 \\
\hline Self Efficacy & 0.837 \\
\hline
\end{tabular}

Source : Data proccesed by author (2021) 
From the results shown in the table, the Cronbach alpha value for each variable is already above 0.70 . This can be concluded that each construction has good reliability in accordance with the minimum value limit that has been determined.

Composite Reliability

Table 6 .Result of Composite Reliability

\begin{tabular}{|lr|}
\hline Dukungan Organisasi & Composite Reliability \\
\hline Keterikatan Kerja & 0.848 \\
\hline Self Efficacy & 0.900 \\
\hline
\end{tabular}

Source : Data proccesed by author (2021)

From the results shown in the table, the value for all constructions on composite reliability is already above the value of 0.70 . It can be concluded that all constructions already have good reliability in accordance with the minimum value limit specified.

Inner Model

R-Square

Table 7. Result of R-Square

\begin{tabular}{|rr}
\hline Keterikatan Kerja & R Square \\
\hline
\end{tabular}

Source : Data proccesed by author (2021)

The results of $\mathrm{R}^{2}$ calculations performed on endogenous latent variables show that the $\mathrm{R}^{2}$ value produces a value of 0.712 and based on this can be concluded indicating that strong $\mathrm{R}^{2}$ or the influence of independent variables on dependent variables is very strong.

Q-Square

Table 8. Results of Q-Square

\begin{tabular}{|l|r|rr|}
\hline & SSO & SSE & $Q^{2}$ (=1-SSE/SSO) \\
\hline Dukungan Organisasi & 200.000 & 200.000 & \\
\hline Keterikatan Kerja & 250.000 & 141.646 & 0.433 \\
\hline Self Efficacy & 250.000 & 250.000 & \\
\hline & SSO & SSE & $Q^{2}$ (=1-SSE/SSO) \\
\hline Dukungan Organisasi & 200.000 & 136.890 & 0.316 \\
\hline Keterikatan Kerja & 250.000 & 134.503 & 0.462 \\
\hline Self Efficacy & 250.000 & 147.112 & 0.412 \\
\hline
\end{tabular}

Source : Data proccesed by author (2021)

Based on the table above All $\mathrm{Q}^{2}$ values have magnitudes above zero, thus demonstrating the predictive relevance of the model over endogenous latent variables. In this research model, endogenous latent constructs or variables have $\mathrm{Q}^{2}$ values greater than zero so that predictions made by the assessed model are relevant. 
F-Square

Table 9. Result of F-Square

Keterikatan Kerja

Dukungan Organisasi
$\begin{aligned} & \text { Keterikatan Kerja } \\ & \text { Self Efficacy }\end{aligned} \quad 0.298$
$\quad$ Source : Data proccesed by author $(\mathbf{2 0 2 1})$

The table above states the following:

a. The effect of organizational support on work engagement has a relatively medium level of influence (F-Square Value 0.298).

b. The effect of self-efficacy on work engagement has a relatively medium level of influence (F-Square Value of 0.213).

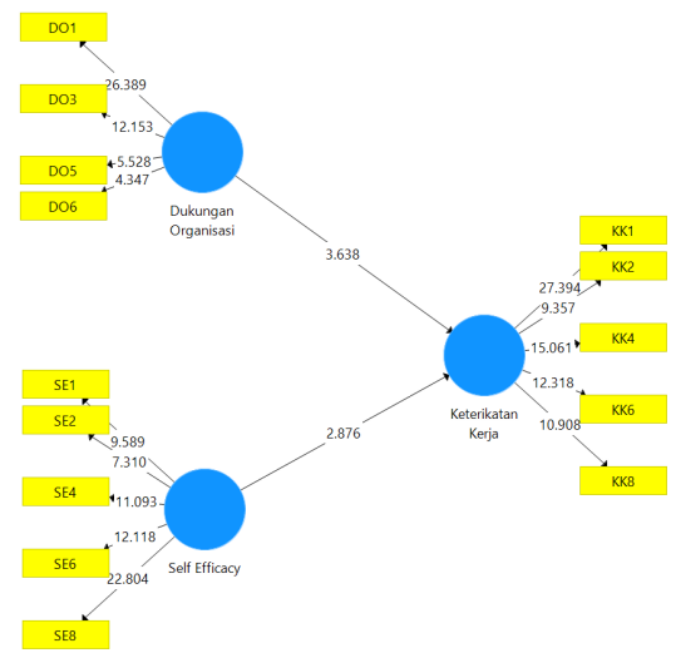

Figure 4. Result for Hypothesis Testing

Source : Data proccesed by author (2021)

In accordance with the bootstrapping results of the highest statement item contained in the statement item in perceived organizational support variable, "I get the appropriate leave allowance for contribution". This means that employees with good contributions, they get reciprocity in the form of good leave allowances. The leave allowance is given by the company so that employees are able to balance their personal life and work life. In the self-efficacy variable, the statement item the highest is "I have many ideas in overcoming difficulties". This means that employees in the company can finish the work with various ideas they have, so that when difficulties arise the employees are able to solve it with these ideas. The work engagement variable has the highest statement item in 
the item "I'm passionate about doing a job". This means that employees in the company have a spirit that is maintained in the work of tasks. Passionate employees will be able to give all the effort they can give to the tasks they have.

The result regarding the highest statement item on bootstrapping is different from the statement item contained in the variable description. This is because for variable descriptions, the highest items are taken based on percentage gains on value weights strongly agree and agree only. On the other hand, on bootstrapping results, the highest acquisition of statement items is viewed based on overall statistics.

Table 10. Results of T-Statistics and P-Value

\begin{tabular}{|lrr|}
\hline Dukungan Organisasi $->$ Keterikatan Kerja & T Statistics (|O/STDEV|) & P Values \\
\hline Self Efficacy $>$ Keterikatan Kerja & 3.638 & 0.000 \\
\hline$\checkmark$ & 2.876 & 0.004 \\
\hline
\end{tabular}

Source : Data proccesed by author (2021)

The table above states the following:

a. Perceived organizational support variables have a significant effect on the work engagement variable indicated by a t-statistical value of 3,638>1.96 and a p-value of $0.000<0.05$.

b. Self efficacy variable has a significant effect on the variable working engagement indicated by the t-statistical value of $2,876>1.96$ and the $p$-value of $0.004<0.05$.

c. Perceived organizational support variables and self efficacy together have a significant effect on the variable of work engagement indicated by a t-statistical value of $21,990>1.96$ and a p-value of $0.000<0.05$.

In the criteria related to acceptance and rejection of hypotheses that have been made, then if the t-statistic is more than the value of 1.96 and the probability is less than 0.05 , then Ha can be accepted, and Ho is rejected. There is a positive and significant influence among perceived organizational support and self-efficacy on work engagement and the significant influence directly from perceived organizational support variables and selfefficacy on work engagement. 


\section{CONCLUSION}

Perceived organizational support has a positive and significant effect on the work engagement of employees of PT Bhumi Bhakti Sukses Persada. This statement is the result of a statistical description of t-statistics that have a value of $(3,638>1.96)$ with a significance value of $(0.000<0.05)$. This can be interpreted if the perception that employees have about the support of the company they work for has a positive value, then this will affect their work engagement to be strong.

Self-efficacy has a positive and significant effect on the work engagement of employees of PT Bhumi Bhakti Sukses Persada. This statement is the result of a statistical elaboration of t-statistics that have a value of $(2,876>1.96)$ with a significance value of $(0.004<$ $0.05)$. This can be interpreted if the level of self-efficacy or trust of employees to their ability is high, then the engagement of work they have will be directly proportional to it, or the engagement of work they have is high.

Perceived organizational support and self-efficacy together has a positive and significant influence on work engagement. This statement is the result of the description of t-statistics that have a value of $(21,990>1.96)$ with a significance value of $(0.000<0.05)$. This can be interpreted that in this study, the two variables used were able to influence together with the engagement of work.

The results of this study show that perceived organizational support has a positive and significant influence on work engagement. The results support research conducted previously by Utari et al. (2021), which provides a statement that the work engagement owned by employees is caused by the positive attitude of employees, who are the result of enthusiasm, happiness, and satisfaction obtained by employees in their work lives. The results of this study also support the results of previous research conducted by Sunarjo et al. (2020), Sitorus (2018), Najeemdeen et al. (2018); the three results of the study where there is a positive and significant influence of perceived organizational support for work engagement.

The results of this study showed that self-efficacy has a positive and significant influence on work engagement. The results support research conducted previously by Pulungan \& Rivai (2021), which states that the higher the level of self-efficacy owned by an employee, then they will be less likely to experience emotional dissonance that can make an 
employee's work attachment decrease. The results of this study also support the results of previous research conducted by Ariani \& Nugroho (2019), Trilolita et al. (2017), Fajriah $\&$ Darokah (2016), whose results from these three studies stated that there is a positive and significant influence of self-efficacy on work engagement.

The results of this study showed perceived organizational support and self-efficacy had a positive and significant effect on work engagement. The results support research conducted earlier by Hasnida et al. (2019), which stated that perceived organizational support and self-efficacy positively affect work engagement. Similarly, research conducted by Sulistyo \& Suhartini (2019) states the same thing and gives the opinion that employees with a good perceived organizational support will give a positive attitude towards the work, as well as those who have good self-efficacy will show confidence when facing difficulties in doing work in various situations and conditions.

Practical Implications

Perceived organizational support variable, the statement item with the highest number of responses (5) and agree (4) is the item "I get help from the company when experiencing a difficulty" with a percentage of $94.2 \%$. This has the implication that as many as $94.2 \%$ of employees at PT Bhumi Bhakti Sukses Persada get any assistance from the company when they are experiencing difficulties in both personal life and work life. Therefore, it's good for the company to maintain a positive attitude toward employees so that in the future, it can bring even better influence for employees or the company itself.

In the variable self-efficacy item statement with the highest number of responses (5) and agree (4) is the item "I always succeed in doing a difficult task when trying," with a percentage of $95.8 \%$. This has the implication that as many as $95.8 \%$ of employees at PT Bhumi Bhakti Sukses Persada have a desire to complete each task with a high level of difficulty. Therefore, it is good to maintain and improve the abilities possessed by employees, and the company conducts training or self-development of employees so that their abilities can be honed. It is also able to make the company produce human resources that are professional in doing the work.

In work engagement variables of statement items with the highest number of responses (5) and agree (4) items, i.e. the item "I feel time passes quickly while doing work" with a percentage of $95.8 \%$. This has the implication that as many as $95.8 \%$ of employees at PT 
Bhumi Bhakti Sukses Persada feel that time will quickly pass when they do their work. Therefore, it's a good thing for companies to pay extra attention to employees to provide reciprocity that is worth what employees give through the work they do.

Suggestions. Companies can overcome the problems that occur regarding perceived organizational support in several ways by looking at one of the problems contained in the question item in this study, one of which is in the item "I am not replaced by someone else with a lower salary". In this item, there are still employees who feel strongly disagree and disagree with the statement. This shows that a small percentage of employees who fill out questionnaires sometimes feel replaced by other individuals who agree to be paid less than them. It's good, to overcome this, the company can discuss again with employees who will be replaced what the things that must be changed both for the company and employees so that the best decisions can be made are.

Companies can solve problems that occur about self-efficacy in several ways by looking at one of the problems contained in the question item in this study, one of which is in the items "I can't solve every problem that occurs" and "I can't handle well unexpected events". This shows that there are still employees who feel that they have not been able to solve unexpected problems and events. It's good; companies can provide training to develop themselves so that they are able to hone their skills so that they are stronger in doing their tasks even though unexpected things will happen.

The company can overcome the problems that occur regarding work engagement in several ways by looking at one of the problems contained in the question item in this study, one of which is in the item "I feel uninspired by the work done". This shows that there are still employees who feel the work they do can not inspire them. It's good, and the company can provide an explanation of the company's values that can be embraced by workers while they work. Companies can also provide challenges in work so that employees will feel a variety in work.

\section{References}

Albrecht, S. L. (2010). Handbook of employee engagement. Edward Elgar Press.

Bakker, A. B., \& Demerouti, E. (2008). Towards A Model of Work Engagement. Career Development

International,

13(3),

209-223. 
https://doi.org/10.1108/13620430810870476

Bandura, A. (1997). Self Efficacy : The Exercise of Control. W.H. Freeman and Company.

Cervone, D., \& Pervin, L. A. (2012). Kepribadian: Teori dan Penelitian. Salemba Humanika.

Friedman, H. S., \& Schustack, M. W. (2008). Kepribadian Teori Klasik dan Riset. Erlangga.

Ghani, N. A. A., \& Hussin, T. A. B. S. R. (2009). Antecedents of Perceived Organizational Support. Canadian Social Science, 5. https://doi.org/10.1037/12318003

Ghozali, I., \& Latan, H. (2015). Partial least squares: Konsep, teknik, dan aplikasi menggunakan program smart PLS 3.0 (2nd ed.) (2nd Editio). Universitas Diponegoro.

Hasnida, Samosir, A. J., \& Novliadi, F. (2019). The Effect of Perceived Organizational Support and Self Efficacy towards Work Engagement. International Journals of Sciences and High Technologies, 16(02), 113-117. https://doi.org/10.2991/icebef18.2019.148

Leiter, M. P., \& Bakker, A. B. (2010). Work Engagement: A Handbook of Essential Theory and Research. In Psychology Press.

Macey, W. H. (2006). Toward a definition of engagement. Society for Industrial and Organizational Psychology 21st Annual Conference.

Najeemdeen, I. S., Abidemi, B. T., Rahmat, F. D., \& Bulus, B. D. (2018). Perceived Organizational Culture and Perceived Organizational Support on Work Engagement. Academic Journal of Economic Studies, 4(3), 199-208.

Neves, P., \& Eisenberger, R. (2014). Perceived Organizational Support and Risk Taking. Journal of Managerial Psychology, 29(2), 187-205. https://doi.org/10.1108/JMP07-2011-0021

Rhoades, L., \& Eisenberger, R. (2002). Perceived Organizational Support: A Review of The Literature. Journal of Applied Psychology, 87(4), 698-714. https://doi.org/10.1037/0021-9010.87.4.698

Robbins, S. P., \& Judge, T. A. (2017). Organizational Behavior, Seventeenth Edition, Global Edition. Pearson Education Limited, 747. 
Schaufeli, W. B., \& Bakker, A. B. (2004). Utrecht Work Engagement Scale Preliminary Manual Version 1.1. Occupational Health Psychology Unit Utrecht University, December, 1-60. https://doi.org/10.1037/t01350-000

Schaufeli, Wilmar B., Salanova, M., Gonzalez-Roma, V., \& B.Bakker, A. (2002). The Measurement of Engagement and Burnout: A Two Sample Factor Analytic Approach. Journal of Happiness Studies, 3, 71-92.

Schmidt, F. (2004). Workplace Well-Being in The Public Sector- A Review of The Literature and The Road A Head. Public Service Human Resources Management Agency of Canada.

http://www.hrmaagrh.gc.ca/hrWh/wlbpseeoppfps/documents/Workplac

Sitorus, F. (2018). The Influence of Perceived Organizational Support and Internal Communication toward Work Engagement. 136(Icosop 2017), 280-287. https://doi.org/10.2991/icosop-17.2018.44

Sulistyo, A. R., \& Suhartini, S. (2019). The Role of Work Engagement in Moderating the Impact of Job Characteristics, Perceived Organizational Support, and Self-Efficacy on Job Satisfaction. Integrated Journal of Business and Economics, 3(1), 15. https://doi.org/10.33019/ijbe.v3i1.112

Sunarjo, R., Bernarto, I., Sudibjo, N., \& Santoso, M. (2020). The Relationship between Perceived Organizational, Perceived Supervisor Support, and Need Achievement to Work Engagement of School Organization. International Journal of Economics and Business Administration, VIII(Issue 4), 488-504. https://doi.org/10.35808/ijeba/601 Utari, H. D., Prakoso, H., \& Putera, V. S. (2021). Pengaruh Perceived Organizational Support Terhadap Employee Engagement Pada Karyawan Produksi. Prosiding Psikologi, 07(1). 


\section{Appendix}

\section{Questionnaire Sheet}

1. Work Engagement

\begin{tabular}{|c|c|c|c|c|c|c|}
\hline No. & STATEMENT & 1 & 2 & 3 & 4 & 5 \\
\hline \multicolumn{7}{|c|}{ Vigor } \\
\hline 1. & I am passionate about doing a job & & & & & \\
\hline 2. & I feel capable of doing a job & & & & & \\
\hline 3. & $\begin{array}{l}\text { I feel unprepared for work when I } \\
\text { wake up in the morning }\end{array}$ & & & & & \\
\hline \multicolumn{7}{|c|}{ Dedication } \\
\hline 4. & $\begin{array}{l}\text { I feel strong physically and } \\
\text { mentally in doing my job }\end{array}$ & & & & & \\
\hline 5. & $\begin{array}{l}\text { I can survive in all situations and } \\
\text { conditions in doing the work }\end{array}$ & & & & & \\
\hline 6. & I have a high enthusiasm for a job & & & & & \\
\hline \multicolumn{7}{|c|}{ Absorption } \\
\hline 7. & I feel uninspired by the work done & & & & & \\
\hline 8. & $\begin{array}{l}\text { I feel like time passes quickly } \\
\text { while doing work }\end{array}$ & & & & & \\
\hline
\end{tabular}

2. Perceived Organizational Support (X1)

\begin{tabular}{|r|c|r|r|r|r|r|}
\hline No. & STATEMENT & 1 & 2 & 3 & $\mathbf{4}$ & $\mathbf{5}$ \\
\hline 1. & $\begin{array}{l}\text { I get a leave allowance that } \\
\text { corresponds to my contribution }\end{array}$ & & & & \\
\hline 2. & $\begin{array}{l}\text { I was not given a promotional } \\
\text { opportunity to improve my } \\
\text { career }\end{array}$ & & & & \\
\hline
\end{tabular}




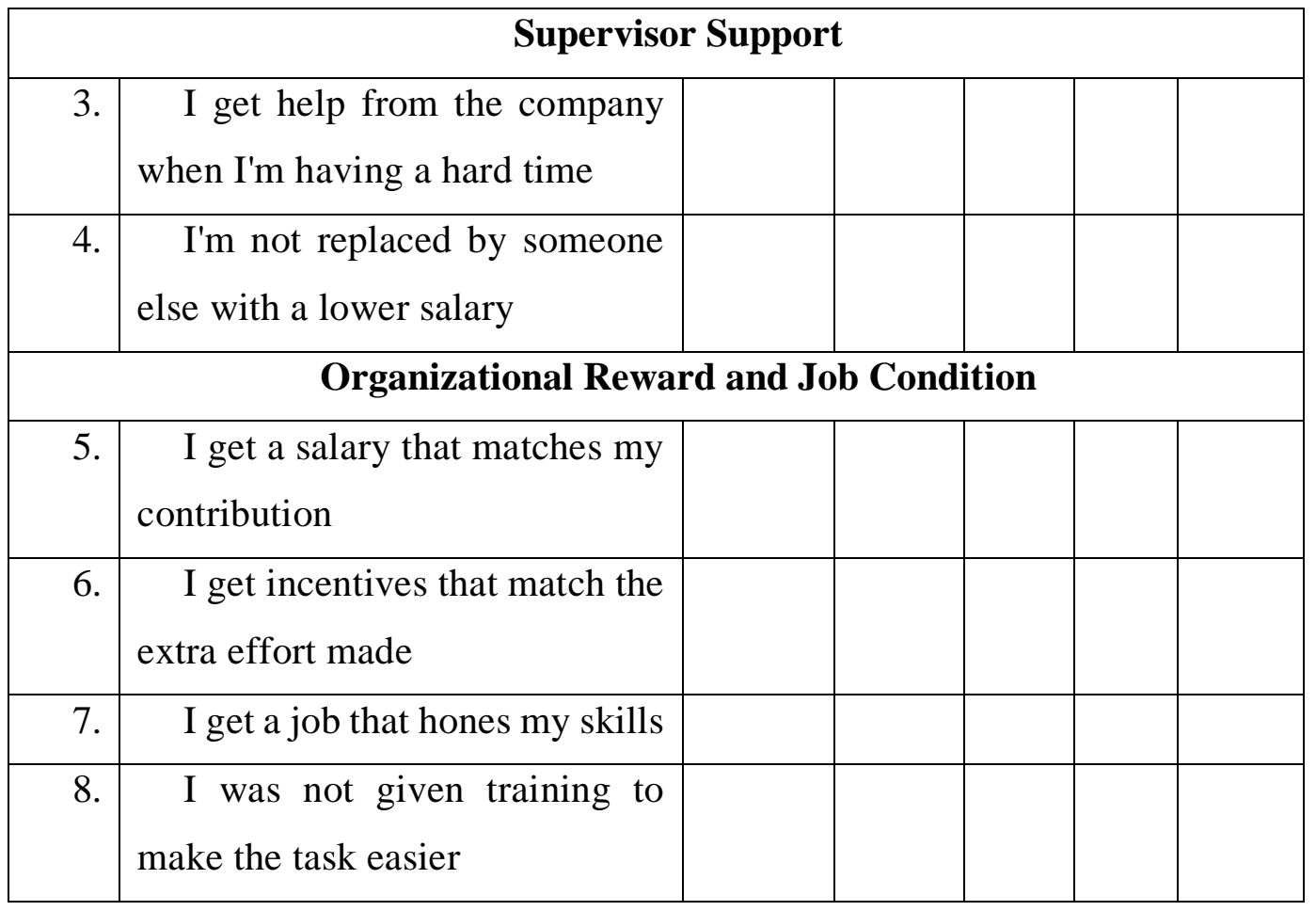

\section{Self Efficacy (X2)}

\begin{tabular}{|c|c|c|c|c|c|c|}
\hline No. & STATEMENT & 1 & 2 & 3 & 4 & 5 \\
\hline \multicolumn{7}{|c|}{ Level } \\
\hline 1 . & $\begin{array}{l}\text { I always manage to do } \\
\text { difficult tasks when trying to }\end{array}$ & & & & & \\
\hline 2. & $\begin{array}{l}\text { I'm looking for new ways and } \\
\text { strategies when someone is } \\
\text { hampering their goals }\end{array}$ & & & & & \\
\hline 3. & $\begin{array}{l}\text { I will always be ready to } \\
\text { handle the situation and } \\
\text { conditions that occur }\end{array}$ & & & & & \\
\hline \multicolumn{7}{|c|}{ Strength } \\
\hline 4. & $\begin{array}{l}\text { I behave according to the } \\
\text { situation and conditions that } \\
\text { occur }\end{array}$ & & & & & \\
\hline
\end{tabular}




\begin{tabular}{|r|l|l|l|l|l|l|}
\hline 5. & $\begin{array}{l}\text { I can't solve every problem } \\
\text { that occurs }\end{array}$ & & & & & \\
\hline 6. & $\begin{array}{l}\text { I always face difficulties by } \\
\text { relying on the ability and calm } \\
\text { carrying }\end{array}$ & & & & & \\
\hline 7. & $\begin{array}{l}\text { I can't handle well unexpected } \\
\text { events }\end{array}$ & & & & \\
\hline 8. & I have many ideas in & & & & & \\
\hline
\end{tabular}

